\title{
High time to omit oxygen therapy in ST elevation myocardial infarction
}

\author{
Ardavan Khoshnood ${ }^{1,2}$ (D)
}

\begin{abstract}
Supplemental oxygen $\left(\mathrm{O}_{2}\right)$ therapy in patients with chest pain has been a cornerstone in the treatment of suspected myocardial infarction (MI). Recent randomized controlled trials have, however, shown that supplemental $\mathrm{O}_{2}$ therapy has no positive nor negative effects on cardiovascular functions, mortality, morbidity or pain in normoxic patients with suspected MI and foremost patients with ST Elevation Myocardial Infarction (STEMI). $\mathrm{O}_{2}$ therapy in normoxic STEMI patients should therefore be omitted. More studies are needed in discussing hemodynamically unstable STEMI patients, as well as patients with non-STEMI, unstable angina and other emergency conditions.
\end{abstract}

Keywords: Oxygen, Oxygen therapy, ST elevation myocardial infarction, STEMl, Physiology, Pathology, Emergency medicine

\section{Main text}

ST Elevation Myocardial Infarction (STEMI) is the most serious manifestation of Acute Coronary Syndrome (ACS) and is by the Fourth Universal Definition of Myocardial Infarction deemed to be a Type I myocardial infarction, caused by an acute atherothrombotic coronary artery disease (CAD) [1]. The consequence of CAD is a partial or complete occlusion of a coronary artery thus contributing to the termination of oxygen $\left(\mathrm{O}_{2}\right)$ supply to the myocardium, giving rise to ischemia $[1,2]$.

Because of its seriousness, prompt and rapid diagnosis and treatment is of high importance to reduce both mortality and morbidity [3]. The most important treatment in STEMI is Percutaneous Coronary Intervention (PCI), which should be performed as soon as possible after that the condition is diagnosed [4-6].

International guidelines also emphasize on treatment with dual antiplatelets in the emergency phase before the start of the PCI [4-6]. Previous guidelines also recommended the immediate administration of $\mathrm{O}_{2}$ to patients with diagnosed or suspected ACS, without any respect to the blood $\mathrm{O}_{2}$ saturation [7-10]. In discussing current guidelines, only the 2017 ESC Guidelines for the management of patients with STEMI [5] states that $\mathrm{O}_{2}$ should not routinely be administrated to patients with

\section{Correspondence: ardavan.khoshnood@med.lu.se}

${ }^{1}$ Department of Clinical Sciences, Faculty of Medicine, Lund University, Lund, Sweden

2Department of Emergency and Internal Medicine, Skåne University Hospital Lund, Lund, Sweden

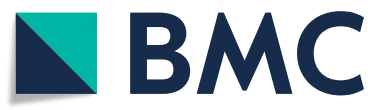

STEMI, and that only those with a blood $\mathrm{O}_{2}$ saturation $<90 \%$ or $\mathrm{PaO}_{2}<60 \mathrm{mmHg}$ should receive $\mathrm{O}_{2}$ therapy.

With an overwhelming scientific evidence that $\mathrm{O}_{2}$ therapy has no positive (nor negative) effects in patients with STEMI, all international, regional and local guidelines should be updated and omit $\mathrm{O}_{2}$ therapy in normoxic ( $\geq 90 \%)$ STEMI patients.

\section{Oxygen therapy}

The history of $\mathrm{O}_{2}$ as a medicine dates back to 1775 when the British chemist Joseph Priestly discovered $\mathrm{O}_{2}$ and stated that it could be used as a medicine [11]. It was, however, in 1900 that the first publication on the role of $\mathrm{O}_{2}$ therapy in patients with chest pain was published. It was a short letter by Dr. Charles Steele, in which he deemed that $\mathrm{O}_{2}$ therapy had relieved chest pains in one single patient he believed to have angina [12]. Ever since this letter by Dr. Steele, several studies have tried to answer how supplemental $\mathrm{O}_{2}$ therapy in both healthy and ill patients affect their cardiovascular system.

The rationale behind $\mathrm{O}_{2}$ therapy has been that by adding $\mathrm{O}_{2}$ to the patient's blood, the myocardium can be oxygenated, which in turn will contribute to a diminished ischemic area and infarct size, thereby minimizing the risk for lethal arrhythmias [13, 14]. Studies on canines [14-16] have given some support to this theory, showing that $\mathrm{O}_{2}$ therapy decreases infarct size and ischemia in these animals. A recent study on swine, however, showed that hyperoxemia can aggravate and worsen myocardial ischemia [17].

(c) The Author(s). 2018 Open Access This article is distributed under the terms of the Creative Commons Attribution 4.0 International License (http://creativecommons.org/licenses/by/4.0/), which permits unrestricted use, distribution, and reproduction in any medium, provided you give appropriate credit to the original author(s) and the source, provide a link to the Creative Commons license, and indicate if changes were made. The Creative Commons Public Domain Dedication waiver (http://creativecommons.org/publicdomain/zero/1.0/) applies to the data made available in this article, unless otherwise stated. 
In healthy individuals, experimental studies have shown that hyperoxemia because of supplemental $\mathrm{O}_{2}$ therapy, may contribute to negative cardiovascular effects like a decrease in coronary blood flow, arterial vasoconstriction, diminished cardiac output, an increase in the systemic vascular resistance as well as impaired blood flow to organs and tissues [18-26].

In patients with suspected as well as confirmed myocardial infarction, the role of $\mathrm{O}_{2}$ were for a long time highly inconclusive. Our knowledge gap in this matter was not because of lack of studies, but rather because of the poor methodologies used in these studies. Ever since 1900, several studies have been published on the role of $\mathrm{O}_{2}$ in patients with chest pain, coronary artery disease, cardiac failure as well as suspected and confirmed myocardial infarction. All of them have unfortunately had serious limitations and have therefore not been able to correctly answer the question of how $\mathrm{O}_{2}$ therapy affects the cardiovascular system in both healthy patients and patients with myocardial infarction and cardiac failure. The studies have either been case studies or small reports including only a few patients, thus not being generalizable, or small studies [18-20, 27-43]. Furthermore, the vast majority of the studies was conducted in the pre-PCI era and even before Troponin was used as an important part in the diagnosis of myocardial infarction.

Because of the above limitations, a Cochrane report from 2013 [44] called for randomized controlled trials to once for all answer the question about which role supplemental $\mathrm{O}_{2}$ therapy should have in patients with chest pain and suspected myocardial infarction. The authors of the report stated that "A definitive randomised controlled trial is urgently required [...]."

\section{Randomized controlled trials}

Before the Cochrane reports call for a definitive randomized controlled trial (RCT) in 2013, there were already four RCTs on the role of supplemental $\mathrm{O}_{2}$ in patients with myocardial infarction; Rawles et al. from 1976 [45], Wilson et al. from 1997 [42], Ukholkina et al. from 2005 [46] and Ranchord et al. from 2012 [47].

The two first studies were conducted in the pre-PCI era. While Wilson et al. [42] found no significant differences between the patients with myocardial infarction randomized to supplemental $\mathrm{O}_{2}$ or air, Rawles et al. [45] showed that patients with myocardial infarction receiving supplemental $\mathrm{O}_{2}$, had a larger infarct size as measured with serum aspartate aminotransferase.

The study by Ukholkina et al. [46] is the only randomized study showing a positive effect of supplemental $\mathrm{O}_{2}$ therapy in patients with myocardial infarction. The study is thus highly biased because of a limited methodology [44].

Rancord et al. [47] have a sound methodology, and should be considered the first modern RCT on the role of supplemental $\mathrm{O}_{2}$ in patients with STEMI. The authors found no significant differences between the two arms (supplemental $\mathrm{O}_{2}$ vs titrated $\mathrm{O}_{2}$ ) with regard to infarct size as measured by cardiac Troponin $\mathrm{T}$, as well as cardiac MRI (CMRI) close to one month after inclusion.

After the Cochrane report from, three more RCTs have been published discussing the role of supplemental $\mathrm{O}_{2}$ therapy in myocardial infarction; the AVOID study $[48,49]$, the SOCCER study [50-53] and the DETO2X study [54-57].

The main publication of the AVOID study was conducted by Stub et al. [48] in which 441 STEMI patients were randomized to supplemental $\mathrm{O}_{2}$ therapy or air. Even though the study found no significant difference in infarct size as measured by cardiac Troponin, a subset of the patients undergoing CMRI after six months, showed that those randomized to supplemental $\mathrm{O}_{2}$ therapy, had a larger infarct size as measured in absolute mass but not in percent of the left ventricle. A sub study [49] of the AVOID trial showed later that patients randomized to the $\mathrm{O}_{2}$ arm, had significantly higher cardiac Troponin rates than those randomized to the air arm.

The SOCCER study was conducted in Sweden by Khoshnood et al. and aimed to evaluate the effects of supplemental $\mathrm{O}_{2}$ in normoxic first-time STEMI patients accepted for PCI. Patients were randomized to either supplemental $\mathrm{O}_{2}$ therapy or air. All patients underwent CMRI, while only a subset of patients underwent echocardiography. Their chest pain was scored and assessed prehospital and in-hospital with the Visual Analog Scale (VAS) [50]. Ninety-four patients underwent CMRI which showed no significant difference between the two arms in discussing infarct size, myocardium at risk and myocardial salvage index [51]. Of the 87 patients undergoing echocardiography, no significant differences could be measured between the two arms in discussing left ventricular ejection fraction and wall motion score index [52]. In a recently published sub study, 111 patients were assessed in regard to chest pain to evaluate the analgesic effect of $\mathrm{O}_{2}$ therapy. Those randomized to the supplemental $\mathrm{O}_{2}$ group had significantly higher median VAS and also received significantly higher amounts of morphine. The study could not show that supplemental $\mathrm{O}_{2}$ diminished chest pain [53].

The DETO2X study was also conducted in Sweden. The main publication by Hofmann et al. included more than 6000 patients and evaluated the one-year-all-cause mortality in normoxic patients with suspected myocardial infarction randomized to supplemental $\mathrm{O}_{2}$ therapy or ambient air. The study found no significant differences between the two arms in regard to mortality nor morbidity [55]. A sub study on patients with only STEMI $(n=2807)$ did not show any significant differences between the two arms in regard to one-year all-cause mortality, or morbidity like 
Table 1 A summary of the randomized controlled trials studying the effects of $\mathrm{O}_{2}$ therapy in patients with suspected or confirmed myocardial infarctions

\begin{tabular}{lll}
\hline Author (Year) & Study Design & Outcome \\
\hline Rawles et al. & Double blind. Inclusion: & IS increased in patients treated with $\mathrm{O}_{2}$ as \\
[45] (1976) & $\begin{array}{l}\text { Suspected MI. Patients } \\
\text { randomized to } \mathrm{O}_{2} \text { or air. }\end{array}$ & $\begin{array}{l}\text { measured by AST. No significant differences } \\
\text { were shown between the arms in discussing } \\
\text { mortality, malignant arrythmias and use } \\
\text { of analgesics. }\end{array}$
\end{tabular}

Limitations

Only those with suspected MI was included, why it is uncertain how many who in fact did had a MI.

The study was conducted pre-PCl era.

IS was measured by AST.

No description of how the randomization sequence was conducted.

Wilson et al.

[42] (1997)

Open label. Inclusion:

Confirmed MI.

Patients randomized

to $\mathrm{O}_{2}$ or air.

Ukholkina et al. Open label. Inclusion: [46] (2005)

Confirmed MI. Patients randomized to $\mathrm{O}_{2}$ or air.

Ranchord et al. Open label. Inclusion: [47] (2012) STEMI/LBBB. Patients randomized to $\mathrm{O}_{2}$ or titrated $\mathrm{O}_{2}$.

Stub et al.

[48] (2015)

Open label. Inclusion: STEMI. Patients randomized to $\mathrm{O}_{2}$ or air.

Patients in the $\mathrm{O}_{2}$ group had a significantly higher mean peak CK but not CTn, increased IS as measured with MRI, and a higher rate of arrythmias as well as recurrent Ml.

Nehme et al.

[49] (2016)

Sub study. The main study was conducted by Stub et al. (2015)

Khoshnood et al. Single blind. Inclusion: No significant differences between the For every $100 \mathrm{~L}$ of $\mathrm{O}_{2}$ given to a patient, both cTnl as well as CK, increased with $1.4 \%$ and $1.2 \%$ respectively. [51] (2017) STEMI. Patients randomized two groups in discussing MSI, MaR and IS. to $\mathrm{O}_{2}$ or air.

Khoshnood et al. Sub study. The main study [52] (2017) was conducted by Khoshnood et al. (2017; ref. 44)

Khoshnood et al. Sub study. The main [53] (2018) study was conducted by Khoshnood et al. (2017; ref. 44).

Hoffman et al.

Open label. Inclusion: [55] (2017)

Hoffman et al [56] (2018)

Sparv et al. [57] (2018)

\section{Suspected MI. Patients} randomized to $\mathrm{O}_{2}$ or air.

Sub study. The main by Hoffman et al. (2017)

Sub study. The main study was conducted by Hoffman et al. (2017). study was conducted
No significant differences between the groups in discussing WMSI, LVEF as well as NT-proBNP.

Before the randomization, patients in the $\mathrm{O}_{2}$ received significantly more morphine.

No significant differences between the two groups in regard to VAS at the start of the $\mathrm{PCl}$ or median $\mathrm{VAS}$ decrease from randomization to $\mathrm{PCl}$.

No significant differences between the groups on all-cause mortality at 1 year.

No significant differences between the groups in discussing all-cause mortality at 1 year, or adverse cardiac events like Ml rehospitalization or cardiogenic chock.

No significant differences between the groups in discussing analgesic effect, or the use of both sedatives and opiates during $\mathrm{PCl}$. group had a significantly higher VAS and also
The study was conducted pre-PCl era.

IS was measured by AST.

$16 \%$ of those initially included, fell out and was thus not analyzed in the final analysis cohort.

The randomization process is unclear.

Many have been excluded without any discussion. IS was measured by CKMB and through ECG mapping.

Data is lacking for a considerable amount of the patients in regard to mortality.

MRI was performed in a subgroup of patients surviving more than 30 days, thus giving rise to a possible selection bias.

$\mathrm{CK}$ is not specific for MI.

MRI was conducted in only some patients, thus giving rise to a possible selection bias.

$M R I$ showed increased IS measured in grams of the $L V$, but not as a percentage of the LV.

See limitations for Sub et al. (2015).

A little over $8 \%$ of the patients were excluded since they had no cTnl measurements.

MRI was conducted in only some patients, thus giving rise to a possible selection bias.

A considerable number of patients were excluded because they, among others, denied participation after that they were initially included. This may be a source of bias.

A considerable amount of the patients missed VAS rates and were therefore excluded. This may be a source of bias.

The study may have been underpowered.

See limitations for Hoffman et al. (2017).

Some of the included patients received opiates in the ambulance, why it may have decreased pain at the $\mathrm{PCl}$.

AMI Acute Myocardial Infarction, AST Aspartate Transaminase, CK Creatine Kinase, CKMB Creatine kinase-MB, cTn Cardiac Troponin, CTnl Cardiac Troponin I, ECG Electrocardiogram, IS Infarct Size, LBBB Left Bundle Branch Block, LV Left Ventricle, LVEF Left Ventricular Ejection Fraction, MaR Myocardium at Risk, MI Myocardial Infarction, MRI Magnetic Resonance Imaging, MSI Myocardial Salvage Index, $\mathrm{O}_{2}$ Oxygen, $\mathrm{PCI}$ Percutaneous Coronary Intervention, STEMI ST Elevation Myocardial Infarction, VAS Visual Analog Scale, WMSI Wall Motion Score Index 


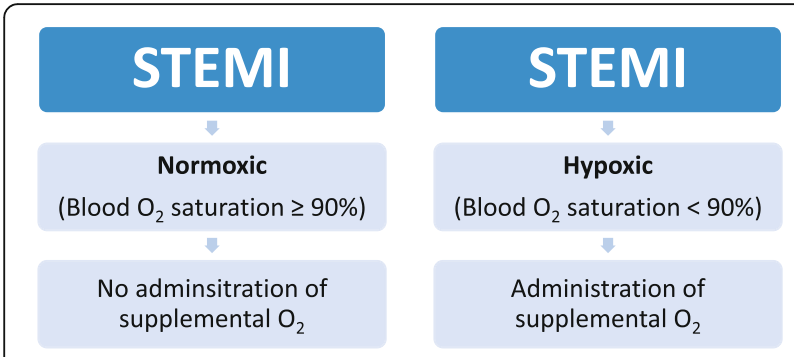

Fig. 1 Suggestion on how to manage patients with ST Elevation Myocardial Infarction (STEMI) both in a prehospital setting and in-hospital

myocardial infarction and cardiogenic shock [56]. In a recent published DETO2X sub study by Sparv et al. [57] on the analgesic effect of supplemental $\mathrm{O}_{2}$ therapy in patients with suspected myocardial infarction, there were no significant differences between the two arms in regard to pain nor the amount of morphine and sedatives received during PCI.

Table 1 summarizes all the RCTs.

\section{Omit supplemental $\mathbf{O}_{\mathbf{2}}$ therapy in STEMI}

The above RCTs clearly show that $\mathrm{O}_{2}$ therapy has so positive nor negative cardiovascular effects, when used in normoxic patients with STEMI both prehospital and in-hospital. Two recent reviews and meta-analysis on the role of supplemental $\mathrm{O}_{2}$ therapy in acute myocardial infarction, showed also no benefit of using $\mathrm{O}_{2}$ therapy in these patients $[58,59]$.

In discussing supplemental $\mathrm{O}_{2}$ therapy in normoxic STEMI patients, the evidences are clear and consistent, why all guidelines must be reformed to state that supplemental $\mathrm{O}_{2}$ therapy in these patients should be omitted. It is, however, of high importance to point that patients diagnosed with STEMI, and who have a low blood oxygen saturation, should receive supplemental $\mathrm{O}_{2}$. It is the routine use of $\mathrm{O}_{2}$ therapy, with no respect to blood oxygen saturation, that should be omitted (Fig. 1). With this said, it is important to point out that the RCTs presented above does also have some limitations as the majority of them have had a small cohort, and the focus have been stable and normoxic STEMI patients. These limitations might reduce the generalizability of the studies. More studies are therefore needed in discussing supplemental $\mathrm{O}_{2}$ therapy in hemodynamic unstable STEMI patients, patients with non-STEMI as well as unstable angina. This is especiCally of importance since some studies argue that supplemental $\mathrm{O}_{2}$ therapy administrated to acutely ill patients can be toxic and increase mortality and morbidity $[60,61]$.

\section{Abbreviations}

ACS: Acute Coronary Syndrome; CAD: Coronary Artery Disease; CMRI: Cardiac Magnetic Resonance Imaging; MI: Myocardial Infarction; $\mathrm{O}_{2}$ : Oxygen;
PCI: Percutaneous Coronary Intervention; RCT: Randomized Controlled Trials; STEMI: ST Elevation Myocardial Infarction; VAS: Visual Analog Scale

\section{Acknowledgements}

Not applicable.

Funding

Not applicable.

Availability of data and materials

Not applicable.

\section{Author's contribution}

The author read and approved the final manuscript.

\section{Authors' information}

Dr. Ardavan Khoshnood is a senior resident in Emergency Medicine, and holds a PhD in Clinical Medicine, Emergency Medicine. He is a lecturer at the Medical Faculty at Lund University, and also serves as an Associate Editor for the BMC Emergency Medicine.

Ethics approval and consent to participate

Not applicable.

\section{Consent for publication}

Not applicable.

\section{Competing interests}

Dr. Khoshnood have authored several articles on the role of supplemental $\mathrm{O}_{2}$ therapy in patients with myocardial infarction and STEMI. Dr. Khoshnood is also an Associate Editor at the BMC Emergency Medicine.

\section{Publisher's Note}

Springer Nature remains neutral with regard to jurisdictional claims in published maps and institutional affiliations.

Received: 30 August 2018 Accepted: 11 October 2018

Published online: 20 October 2018

\section{References}

1. Thygesen K, Alpert JS, Jaffe AS, Chaitman BR, Bax JJ, Morrow DA, White HD, Group ESCSD. Fourth universal definition of myocardial infarction (2018). Eur Heart J. 2018:ehy462.

2. Heusch G, Gersh BJ. The pathophysiology of acute myocardial infarction and strategies of protection beyond reperfusion: a continual challenge. Eur Heart J. 2017;38(11):774-84.

3. Scholz KH, Maier SKG, Maier LS, Lengenfelder B, Jacobshagen C, Jung J, Fleischmann C, Werner GS, Olbrich HG, Ott R, et al. Impact of treatment delay on mortality in ST-segment elevation myocardial infarction (STEMI) patients presenting with and without haemodynamic instability: results from the German prospective, multicentre FITT-STEMI trial. Eur Heart J. 2018;39(13):1065-74.

4. O'gara PT, Kushner FG, Ascheim DD, Casey DE, Chung MK, De Lemos JA, Ettinger SM, Fang JC, Fesmire FM, Franklin BA: 2013 ACCF/AHA guideline for the management of ST-elevation myocardial infarction: executive summary: a report of the American College of Cardiology Foundation/American Heart Association task force on practice guidelines. J Am Coll Cardiol 2013, 61(4): 485-510.

5. Ibanez B, James S, Agewall S, Antunes MJ, Bucciarelli-Ducci C, Bueno H, Caforio ALP, Crea F, Goudevenos JA, Halvorsen S, et al. 2017 ESC guidelines for the management of acute myocardial infarction in patients presenting with ST-segment elevationThe task force for the management of acute myocardial infarction in patients presenting with ST-segment elevation of the European Society of Cardiology (ESC). Eur Heart J. 2018;39(2):119-77.

6. Excellence $\mathrm{NIfHaC}$. Myocardial infarction with ST-segment elevation: acute management. In: NICE guideline (CG167); 2013.

7. Arntz H-R, Bossaert L, Filippatos GS. European resuscitation council guidelines for resuscitation 2005. Resuscitation. 2005;67:587-96.

8. Pollack CV Jr, Diercks DB, Roe MT, Peterson ED. 2004 American College of Cardiology/American Heart Association guidelines for the Management of Patients with ST-elevation myocardial infarction: implications for emergency department practice. Ann Emerg Med. 2005;45(4):363-76. 
9. Nolan JP, Deakin CD, Soar J, Böttiger BW, Smith G. European resuscitation council guidelines for resuscitation 2005. Resuscitation. 2005;67:S39-86.

10. Anderson JL, Adams CD, Antman EM, Bridges CR, Califf RM, Casey DE, Chavey WE, Fesmire FM, Hochman JS, Levin TN, et al. ACC/AHA 2007 guidelines for the Management of Patients with Unstable Angina/non-STelevation myocardial infarction: a report of the American College of Cardiology/American Heart Association task force on practice guidelines (writing committee to revise the 2002 guidelines for the Management of Patients with Unstable Angina/non-ST-elevation myocardial infarction) developed in collaboration with the American College of Emergency Physicians, the Society for Cardiovascular Angiography and Interventions, and the Society of Thoracic Surgeons endorsed by the American Association of Cardiovascular and Pulmonary Rehabilitation and the Society for Academic Emergency Medicine. J Am Coll Cardiol. 2007;50(7):e1-e157.

11. Priestly J. Experiments and observations on different kinds of air, vol. 2 London: St. Paul's Church-Yard; 1775.

12. Steele C. Severe angina pectoris relieved by oxygen inhalations. The British Med J. 1900:1568-8.

13. Madias J, Hood W Jr. Reduction of precordial ST-segment elevation in patients with anterior myocardial infarction by oxygen breathing. Circulation. 1976;53(3 Suppl):1198.

14. Maroko PR, Radvany P, Braunwald E, Hale SL. Reduction of infarct size by oxygen inhalation following acute coronary occlusion. Circulation. 1975;52(3):360-8.

15. Sayen J, Sheldon W, Horwitz O, Kuo PT, Peirce G, Zinsser HF, Mead J. Studies of coronary disease in the experimental animal. II. Polarographic determinations of local oxygen availability in the dog's left ventricle during coronary occlusion and pure oxygen breathing. J Clin Invest. 1951;30(9):932-40.

16. Kelly RF, Hursey TL, Parrillo JE, Schaer GL. Effect of $100 \%$ oxygen administration on infarct size and left ventricular function in a canine model of myocardial infarction and reperfusion. Am Heart J. 1995;130(5):957-65.

17. Guensch DP, Fischer K, Shie N, Lebel J, Friedrich MG. Hyperoxia exacerbates myocardial ischemia in the presence of acute coronary artery stenosis in swine. Circ Cardiovasc Interv. 2015;8(10):e002928.

18. Milone SD, Newton GE, Parker JD. Hemodynamic and biochemical effects of 100\% oxygen breathing in humans. Can J Physiol Pharmacol. 1999:77(2):124-30

19. Waring WS, Thomson AJ, Adwani SH, Rosseel AJ, Potter JF, Webb DJ, Maxwell SR. Cardiovascular effects of acute oxygen administration in healthy adults. J Cardiovasc Pharmacol. 2003;42(2):245-50.

20. Rousseau A, Bak Z, Janerot-Sjöberg B, Sjöberg F. Acute hyperoxaemiainduced effects on regional blood flow, oxygen consumption and central circulation in man. Acta Physiol Scand. 2005;183(3):231-40.

21. Bergofsky EH, Bertun P. Response of regional circulations to hyperoxia. J Appl Physiol. 1966;21(2):567-72.

22. Kenmure AC, Murdoch WR, Hutton I, Cameron AJ. Hemodynamic effects of oxygen at 1 and 2 Ata pressure in healthy subjects. J Appl Physiol. 1972; 32(2):223-6.

23. Thomson AJ, Drummond GB, Waring WS, Webb DJ, Maxwell SR. Effects of short-term isocapnic hyperoxia and hypoxia on cardiovascular function. J Appl Physiol. 2006;101(3):809-16.

24. Whitehorn W, Edelmann A, Hitchcock FA. The cardiovascular responses to the breathing of 100 per cent oxygen at normal barometric pressure. Am J Physiol-Legacy Content. 1946;146(1):61-5.

25. Bodetoft S, Carlsson M, Arheden H, Ekelund U. Effects of oxygen inhalation on cardiac output, coronary blood flow and oxygen delivery in healthy individuals, assessed with MRI. Eur J Emerg Med. 2011;18(1):25-30.

26. Eggers $\mathrm{G} \mathrm{Jr}$, Paley H, Leonard J, Warren J. Hemodynamic responses to oxygen breathing in man. J Appl Physiol. 1962;17(1):75-9.

27. Levy RL, Barach AL. The therapeutic use of oxygen in coronary thrombosis. J Am Med Assoc. 1930;94(18):1363-5.

28. EW B. Oxygen in high concentrations for relief of pain: in coronary thrombosis and severe angina pectoris. J Am Med Assoc. 1940;114(16):1512-4.

29. HI R, FD R, CF N. One hundred per cent oxygen in the treatment of acute myocardial infarction and severe angina pectoris. J Am Med Assoc. 1950; 144(5):373-5.

30. Neill WA. Effects of arterial hypoxemia and hyperoxia on oxygen availability for myocardial metabolism: patients with and without coronary heart disease. Am J Cardiol. 1969;24(2):166-71.

31. Haque WA, Boehmer J, Clemson BS, Leuenberger UA, Silber DH, Sinoway LI. Hemodynamic effects of supplemental oxygen administration in congestive heart failure. J Am Coll Cardiol. 1996;27(2):353-7.
32. McNulty PH, King N, Scott S, Hartman G, McCann J, Kozak M, Chambers CE, Demers LM, Sinoway LI. Effects of supplemental oxygen administration on coronary blood flow in patients undergoing cardiac catheterization. Am J Phys Heart Circ Phys. 2005;288(3):H1057-62.

33. Saadjian A, Paganelli F, Levy S. Hemodynamic response to oxygen Administration in Chronic Heart Failure: role of Chemoreflexes. J Cardiovasc Pharmacol. 1999;33(1):144-50.

34. Daly WJ, Behnke RH. Hemodynamic consequences of oxygen breathing in left ventricular failure. Circulation. 1963;27(2):252-6.

35. Mak S, Azevedo ER, Liu PP, Newton GE. Effect of hyperoxia on left ventricular function and filling pressures in patients with and without congestive heart failure. Chest. 2001;120(2):467-73.

36. Bourassa MG, Campeau L, Bois MA, Rico O. The effects of inhalation of 100 per cent oxygen on myocardial lactate metabolism in coronary heart disease. Am J Cardiol. 1969;24(2):172-7.

37. Foster GL, Casten GG, Reeves T, Hurst wSADC. The effects of oxygen breathing in patients with acute myocardial infarction. Cardiovasc Res. 1969;3(2):179-89.

38. Ganz W, Donoso R, Marcus H, Swan H. Coronary hemodynamics and myocardial oxygen metabolism during oxygen breathing in patients with and without coronary artery disease. Circulation. 1972;45(4):763-8.

39. Kenmure A, Murdoch W, Beattie A, Marshall J, Cameron A. Circulatory and metabolic effects of oxygen in myocardial infarction. Br Med J. 1968;4(5627):360-4.

40. Stone GW, Martin JL, de Boer M-J, Margheri M, Bramucci E, Blankenship JC, Metzger DC, Gibbons RJ, Lindsay BS, Weiner BH. Effect of supersaturated oxygen delivery on infarct size after percutaneous coronary intervention in acute myocardial infarction. Circ Cardiovasc Interv. 2009;2(5):366-75.

41. Lancaster R, McNicol M. Oxygen therapy in myocardial infarction. Postgrad Med J. 1967;43(505):706

42. Wilson A, Channer K. Hypoxaemia and supplemental oxygen therapy in the first 24 hours after myocardial infarction: the role of pulse oximetry. J R Coll Physicians Lond. 1997;31(6):657-61.

43. Madias JE, Madias NE, Hood WB. Precordial ST-segment mapping. 2. Effects of oxygen inhalation on ischemic injury in patients with acute myocardial infarction. Circulation. 1976;53(3):411-7.

44. Cabello JB, Burls A, Emparanza Jl, Bayliss S, Quinn T. Oxygen therapy for acute myocardial infarction. The Cochrane database of systematic reviews. 2013;2013(8):CD007160.

45. Rawles J, Kenmure A. Controlled trial of oxygen in uncomplicated myocardial infarction. Br Med J. 1976;1(6018):1121-3.

46. Ukholkina GBKI, Kuchkina NV, Grendo EP, Gofman I. Oxygen therapy in combination with endovascular reperfusion during the first hours of acute myocardial infarction: clinical and laboratory findings. Int J Interv Cardioangiology. 2005;9:45-51.

47. Ranchord AM, Argyle R, Beynon R, Perrin K, Sharma V, Weatherall M, Simmonds M, Heatlie G, Brooks N, Beasley R. High-concentration versus titrated oxygen therapy in ST-elevation myocardial infarction: a pilot randomized controlled trial. Am Heart J. 2012;163(2):168-75.

48. Stub D, Smith K, Bernard S, Nehme Z, Stephenson M, Bray JE, Cameron P, Barger B, Ellims AH, Taylor AJ: Air versus oxygen in ST-segment elevation myocardial infarction. Circulation 2015:CIRCULATIONAHA. 114.014494.

49. Nehme Z, Stub D, Bernard S, Stephenson M, Bray JE, Cameron P, Meredith IT, Barger B, Ellims AH, Taylor AJ. Effect of supplemental oxygen exposure on myocardial injury in ST-elevation myocardial infarction. Heart. 2016; heartjnl-2015-308636.

50. Khoshnood A, Carlsson M, Akbarzadeh M, Bhiladvala P, Roijer A, Bodetoft S, Höglund P, Zughaft D, Todorova L, Erlinge D. The effects of oxygen therapy on myocardial salvage in ST elevation myocardial infarction treated with acute percutaneous coronary intervention: the supplemental oxygen in catheterized coronary emergency reperfusion (SOCCER) study. Cardiology. 2015;132(1):16-21.

51. Khoshnood A, Carlsson M, Akbarzadeh M, Bhiladvala P, Roijer A, Nordlund D, Höglund P, Zughaft D, Todorova L, Mokhtari A. Effect of oxygen therapy on myocardial salvage in ST elevation myocardial infarction: the randomized SOCCER trial. Eur J Emerg Med. 2018;25(2):78-84.

52. Khoshnood A, Akbarzadeh M, Roijer A, Meurling C, Carlsson M, Bhiladvala P, Höglund P, Sparv D, Todorova L, Mokhtari A. Effects of oxygen therapy on wall-motion score index in patients with ST elevation myocardial infarction - the randomized SOCCER trial. Echocardiography. 2017;34(8):1130-7.

53. Khoshnood A, Akbarzadeh M, Carlsson M, Sparv D, Bhiladvala P, Mokhtari A Erlinge $D$, Ekelund $U$. Effect of oxygen therapy on chest pain in patients 
with ST elevation myocardial infarction: results from the randomized SOCCER trial. Scand Cardiovasc J. 2018;52(2):69-73.

54. Hofmann R, James SK, Svensson L, Witt N, Frick M, Lindahl B, Östlund O, Ekelund $\mathrm{U}$, Erlinge $\mathrm{D}$, Herlitz J. DETermination of the role of OXygen in suspected acute myocardial infarction trial. Am Heart J. 2014;167(3):322-8.

55. Hofmann R, James SK, Jernberg T, Lindahl B, Erlinge D, Witt N, Arefalk G, Frick M, Alfredsson J, Nilsson L, et al. Oxygen therapy in suspected acute myocardial infarction. N Engl J Med. 2017;377(13):1240-9.

56. Hofmann R, Witt N, Lagerqvist B, Jernberg T, Lindahl B, Erlinge D, Herlitz J, Alfredsson J, Linder R, Omerovic E, et al. Oxygen therapy in ST-elevation myocardial infarction. Eur Heart J. 2018:39(29):2730-9.

57. Sparv D, Hofmann R, Gunnarsson A, James S, Hedberg C, Lauermann J, Torild P, Omerovic E, Bergström K, Haugen E et al: The analgesic effect of oxygen in suspected acute myocardial infarction. A Substudy of the DETO2X-AMI Trial 2018, 11(16):1590-1597.

58. Abuzaid A, Fabrizio C, Felpel K, Al Ashry HS, Ranjan P, Elbadawi A, Mohamed AH, Barssoum $\mathrm{K}$, Elgendy IY. Oxygen therapy in patients with acute myocardial infarction: a systemic review and meta-analysis. Am J Med. 2018;131(6):693-701.

59. Sepehrvand N, James SK, Stub D, Khoshnood A, Ezekowitz JA, Hofmann R. Effects of supplemental oxygen therapy in patients with suspected acute myocardial infarction: a meta-analysis of randomised clinical trials. Heart. 2018

60. Girardis M, Busani S, Damiani E, et al. Effect of conservative vs conventional oxygen therapy on mortality among patients in an intensive care unit: the oxygen-icu randomized clinical trial. JAMA. 2016;316(15):1583-9.

61. Chu DK, Kim LHY, Young PJ, Zamiri N, Almenawer SA, Jaeschke R, Szczeklik W, Schünemann HJ, Neary JD, Alhazzani W. Mortality and morbidity in acutely ill adults treated with liberal versus conservative oxygen therapy (IOTA): a systematic review and meta-analysis. Lancet. 2018;391 (10131):1693-705.

Ready to submit your research? Choose BMC and benefit from:

- fast, convenient online submission

- thorough peer review by experienced researchers in your field

- rapid publication on acceptance

- support for research data, including large and complex data types

- gold Open Access which fosters wider collaboration and increased citations

- maximum visibility for your research: over $100 \mathrm{M}$ website views per year

At $\mathrm{BMC}$, research is always in progress.

Learn more biomedcentral.com/submissions 